\title{
Dwalings rondom die Heilige Gees
}

\author{
A D PONT
}

\section{Inleidende Opmerkings}

Dit is nou my taak om afsluitend 'n paar opmerkings te maak oor die dwalings wat daar binne die Christendom oor die persoon en werk van God, die Heilige Gees, bestaan. Dit is nie 'n maklike opdrag nie omdat daar heelwat dwalings rondom die persoon en werk van die Heilige Gees bestaan.

Dit is ook nie toevallig dat juis hier, rondom God, die Heilige Gees, so baie dwalings voorkom nie. Dit is dwalings nie net rondom die persoon van die Heilige Gees nie, maar ook dwalings rondom sy werk, dit wat God, die Heilige Gees, doen. As mens Johannes 16:5-15 nalees waar Christus die werk van die Heilige Gees beskrywe, word dit duidelik waarom daar so veel dwalings kan bestaan. Dit word ook duidelik as die derde deel van ons geloofsbelydenis, die Twaalf Artikels, bekyk word. Want nadat ons bely het: Ek glo in die Heilige Gees, gaan ons verder en bely ons geloof in die kerk, die gemeenskap van die heiliges, die vergewing van die sonde, die weeropstanding van die vlees en die ewige lewe. Alles wat volg op ons belydenis van die Heilige Gees is 'n omskrywing van die werk van die Heilige Gees.

Nou kan begryp word waarom 'n onderwerp soos "dwalings rondom die Heilige Gees" ' $n$ mens te staan bring voor 'n onderwerp wat byna geen einde het nie. Daar bestaan immers baie verskille én dwalings oor wat die Skrifte ons leer nie net oor die persoon van die Heilige Gees nie maar ook oor sy werk.

Ter wille van die duidelikheid en die oorsigtelikheid is dit miskien allereers nodig om 'n paar positiewe stellings oor God, die Heilige Gees, te maak en om dan kortliks enkele kardinale misvattings wat hier bestaan, aan te dui.

\section{God, die Heilige Gees, is 'n Persoon}

Dit word dikwels nie goed genoeg besef nie dat God, die Heilige Gees 'n persoon is nie. In die Geloofsbelydenis van Athanasius wat uit die 8e eeu dateer, bely ons saam met die kerk:

"Want die persoon van die Vader is 'n ander, van die Seun 'n ander van die Heilige Gees ' $n$ ander. Maar die Vader, die Seun en die Heilige Gees het één godheid, gelyke eer en mede-ewige majesteit. Hoedanig die Vader is, sodanig is ook die Seun, soda- 
nig is ook die Heilige Gees. Ongeskape is die Vader, ongeskape is die Seun, ongeskape is die Heilige Gees. Onmeetlik is die Vader, onmeetlik is die Seun, onmeetlik is die Heilige Gees. Ewig is die Vader, ewig is die Seun, ewig is die Heilige Gees. Nogtans is dit nie drie ewiges nie, maar één ewige. Net so ook nie drie ongeskapenes of drie onmeetlikes nie, maar een ongeskapene, en een onmeetlike...

En in hierdie Drievuldigheid is niks eerste of laaste nie, niks meeste of minste nie, maar al die drie persone is onderling mede-ewig en volkome aan mekaar gelyk."

God, die Heilige Gees, so bely ons, is 'n persoon net soos die Vader, net soos Jesus Christus.

Nou is daar ' $n$ tweede waarheid wat ons in hierdie verband baie goed moet onthou. Dit is dat daar' $n$ groot afstand en verskil is tussen God, die Skepperheer, en ons mense die skepsele van sy hand. Jesus Christus, God wat mens geword het, kom al nader na ons toe want Hy is hier op ons wêreld uit 'n vrou gebore en het hier tussen ons kom woon. Tog is daar nóg 'n groot afstand tussen Jesus Christus, ons verlosser-Heer, en ons mense wat armsalige sondaars is. Want Jesus Christus wat mens geword het, staan net soos elke ander mens tog teenoor ons, buite onsself.

God, die Heilige Gees, oorbrug egter elke afstand tussen God en onsself. Hy kom na ons toe en Hy woon in ons (Rom 8:9, 11), Hy bid vir ons (Rom 8:26), Hy getuig saam met ons gees (Rom 8:16). Deur die Heilige Gees word die liefde van God in ons harte uitgestort (Rom 5:5) en die mens wat die Heilige Gees ontvang het, is ' $n$ tempel van God (I Kor 3:16; 6:19; e a) en die nuwe geboorte, die bekering van die mens, die geloof in God is alles die gevolg van die werk van God, die Heilige Gees in ons (Joh 3:8). Die Bybel leer ons dan ook dat ons wat sondaar-mense is, die Heilige Gees ontvang en dat Hy in ons is (Joh 14:17, 20:22 en Rom 8:15), dat die Heilige Gees aan die gelowiges gegee is (Rom 5:5 e a) en dat die gelowiges die Heilige Gees besit of het (II Kor 4:13).

Ons kan dus stel dat God, die Heilige Gees, die afstand tussen God en mens oorbrug en inkom of ingaan in ons lewe so dat dit byna lyk asof die Heilige Gees, wat God is, één met ons word.

Juis hierdie waarheid skep vir ons voortdurend 'n probleem omdat ons voortdurend geneig is om God, die Heilige Gees, met ons eie menslike gees te verwar. Dan vergeet ons dat die Heilige Gees God is en dink ons dat die Heilige Gees maar net 'n mag of 'n krag van God is wat aan ons gegee word èn waaroor ons kan beskik en wat aan ons ondergeskik is.

Voortdurend moet ons vashou aan ons belydenis dat die Heilige 
Gees God is wat, hoewel Hy na ons toe kom en in ons woon, tog altyd God bly. Die feit dat die Heilige Gees in ons woon, beteken nooit dat die mens nou 'n klein godjie word nie of dat ons sondeloos word of dat ons wat mens is aan God kan voorskryf of aan God eise kan stel nie.

Hier is die vraag natuurlik hoe ons dan onderskeid kan en moet maak tussen God, die Heilige Gees wat in ons woon en ons eie, menslike gees en denke. Daarop sal ons effens later ingaan.

'n Ander saak wat ons hier moet onthou om nie met ons gedagtes te verdwaal is nie, is dat die Heilige Gees 'n goddelike persoon in die ewige Drie-eenheid wat God is, net soos Jesus Christus, net soos die Vader. Miskien kan mens dit so duidelik maak. As ons Heer Jesus Christus sy werk op aarde voltooi het, dan vaar Hy op na die hemel. Eers tien dae nà Christus se hemelvaart is die Pinkster, wanneer die Heilige Gees eens en vir altyd uitgestort word. Dit is nie sonder betekenis dat daar tien dae tussen Hemelvaart en Pinkster verloop nie. Dit dui vir ons aan dat Jesus Christus se werk voltooi is en dat God dan met ' $n$ verdere aspek van sy heilsplan kom.

Wanneer Jesus Christus opgevaar het na die hemel en aan die regterhand van God, die Vader sit, dán kom God, die Heilige Gees, na ons en ons wêreld om alles wat Jesus Christus vir ons verwerf het, ook inderdaad aan ons te gee, dit tot ons eiendom te maak en om ons in besit te neem en te omvorm sodat ons Jesus Christus sal glo en so deel sal hê aan sy verlossingswerk.

Hier moet ons dus sê: Alléén deur die werk van God, die Heilige Gees, is dit vir my moontlik om in die Heer Jesus Christus te glo. Geloof is nié 'n prestasie wat ek as mens lewer nie maar dit is 'n gawe van God, 'n gawe wat God, die Heilige Gees, aan my skenk.

Met ander woorde ons moet wel duidelik onderskei tussen ons Heer Jesus Christus en die Heilige Gees. Terselfdertyd is dit natuurlik óók ' $n$ feit dat die Heilige Gees baie nou met Jesus Christus verbonde is (vergelyk Gal 4:5, Rom 8:9, I Pet 1:11). Immers die Skrif leer ons dat die Heilige Gees Jesus Christus sal verheerlik en wat Hy van Christus sal ontvang, sal Hy verkondig (Joh 16:14).

Uit die kerkgeskiedenis kan ons maklik leer dat as mens hierdie noue verband tussen Jesus Christus en die Heilige Gees vergeet of verwaarloos ' $n$ mens geneig is om Jesus Christus en alles wat Hy is en gedoen het, op die agtergrond van ons denke stoot. Dan gebeur dit dat mens van die Heilige Gees ' $n$ nuwe of ' $n$ verdere openbaring verwag wat anders is as wat die Skrifte ons vertel. Daarom sê die Geloofsbelydenis van Nicea ook so duidelik dat die Heilige Gees "van die Vader én die Seun uitgaan". Ons moet altyd daarteen waak om die Heilige Gees nié te verstaan as 'n goddelike krag wat los van Christus staan nie. Die Heilige Gees is nié 'n onpersoonlike gees of 
mag wat los van die Vader of die Seun staan nie. Die Heilige Gees is God, net soos die Vader en die Seun. Hy is God wat tot by ons kom, wat ons persoonlik aanspreek, aanraak en ons omvorm.

Miskien moet ons dit so sê: Die Heilige Gees is God wat die Woord, die Skrifte, die Bybel gebruik om deur die verkondigde en gelese Woord in ons lewe te kom, so die geloof in ons te wek en dit te versterk. Met ander woorde daar bestaan 'n besonder intieme band tussen die Heilige Gees en die Bybel, 'n band wat nooit losgelaat word nie. Nou is die opvallende dat God, die Heilige Gees, mense gebruik om die Woord van God, die Bybelse boodskap, uit te dra en te verkondig om so die geloof te wek in die harte van mense, om so Christus se kerk en sy koninkryk te vestig en uit te bou.

\section{Die Dwaling van die Mistiek}

Miskien is dit, vir die doeleindes van hierdie gesprek, die beste as slegs 'n paar kategorieë van dwalings aangewys word in plaas daarvan dat afsonderlike misvattings rondom die persoon en werk van die Heilige Gees bespreek word.

As ' $n$ eerste kan dan na die mistiek verwys word. As 'n mens dit kortweg wil omskryf, kan gesê word dat die mistiek 'n opvatting en ook ' $n$ beweging is wat die ideaal nastreef om deur kontemplasie, om deur voortdurende innerlike geestelike konsentrasie en inspanning as ' $t$ ware geestelik uit te styg uit die liggaam om dan een te word met die ewige gees wat God is. Dit gebeur omdat die mistieke denke sterk afwysend staan teenoor alles wat wêrelds, stoflik of liggamlik is. Dit word as die sondige beskou. Daarteenoor word die mens se gees of siel as die enigste belangrike beskou. Die mens se gees of siel word selfs gesien as 'n vonkie goddelikheid wat in die liggaam vasgevang is. Die doel van die godsdiens, die bepeinsing en kontemplasie is om die siel of gees los te maak van die liggaamlik-stoflike sodat die mensegees kan uitstyg uit die liggaam om so één te word met die ewige Gees was God is.

Hoewel in die Protestantisme die mistiek nie 'n besondere vastrapplek of groeikans het nie, groei en bloei die mistiek veral in die Roomse kloosterlewe. Buite die Christendom kom dit veral in die Hindoeïsme en die Boeddhisme voor en derglike oosterse mistiese godsdienste. Baie van die sogenoemde "goeroe's" wat deesdae ook in ons samelewing opgemerk word en mense uitnooi om hulle lesings en praktyke by te woon, verkondig een of ander mistiese leer wat dan aan die mens rus, vrede en geluk in die woelige en sondige ondermaanse sal bied.

Waar die mistiek binne die Christendom voorkom, misken dit veral die objektiewe verlossingswerk van Jesus Christus. Nie Jesus 
Christus, die gekruisigde en opgestane Heer, is belangrik nie maar die mens self wat deur kontemplasie, bepeinsing en geestelike oefeninge homself kan verlos deur uit te styg, met sy gedagtes uit die aards-stoflike en so een te word met die ewige Gees wat God is.

Hier word God uitsluitend verstaan as Gees. Dit is dan egter nie meer dieselfde God as dié een waarvan die Skrifte ons vertel nie want die band wat die Heilige Gees aan Jesus Christus en met die Woord van God verbind, word heeltemal losgemaak.

In die mistiek word vergéét dat die Skrifte ons leer dat die Heilige Gees ' $n$ persoon is en nié ' $n$ vae, swewende gees nie. Terselfdertyd word vergeet dat daar 'n groot afstand tussen die sondaar-mens en God bestaan. Daardie afstand kan nié deur die mens self oorbrug word nie hoewel dit deur Jesus Christus oorbrug is. Weer moet ons sê dat die Skrifte ons juis leer dat die soektog van die mens na God die mens nie by God self uitbring nie. Dit is alleen daar waar God die mens soek èn vind wanneer God die Heilige Gees die evangelieboodskap tot by ons bring sodat ons dit hoor en glo, dat die mens die vergewing van die sonde ontvang en kind van God genoem word ondanks alles wat hy is. Dit is en bly 'n dwaling om te dink dat God, die Heilige Gees, ' $n$ vae, algemene gees is wat die mens self deur kontemplasie of deur geestelike oefeninge self kan bereik of kan verwerf. Laat ons liewer vashou aan die waarheid dat God, die Heilige Gees, mense gebruik om die Woord, die goeie boodskap te verkondig sodat ons almal dit kan hoor en kan glo en dat so die geloof in ons gewek en gebou word.

\section{Die Dwalinge van die Geesdrywery}

Dit is en bly waar dat ons duidelik tussen Jesus Christus, die gekruisigde en opgestane Heer, en die Heilige Gees moet onderskei. Tog is dit net so waar dat ons Jesus Christus en die Heilige Gees nie in ons denke van mekaar moet losmaak nie. As dit gebeur, is ons wat mense is geneig om Jesus Christus en die verlossing wat Hy vir ons bewerk het, op die agtergrond te stel. Dan verwag ons van die Heilige Gees 'n nuwe, of ' $n$ verdere openbaring van God wat anders of beter sou wees as die boodskap van die Bybel.

Hierdie soort denke kom nogal dikwels in die Christendom voor en in die lang geskiedenis van die kerk kry ons talle voorbeelde van mense wat hierdie fout gemaak het en as gevolg daarvan die goeie boodskap van die Bybel heeltemal skeef getrek en skeef verstaan het. Een van die eerste persone wat juis op hierdie punt gedwaal het, was Montanus wat in die jare rondom 150 in Frigië gewoon en gewerk het. Hy het 'n nuwe uitstorting van die Heilige Gees verwag en ook gedink dat die terugkeer van Jesus Christus na ons aarde baie naby was. Daarom het hy ' $n$ boodskap verkondig dat die mense uit die 
wêreld moet wegvlug, dat hulle hulle van al hulle sondes moet bekeer en moes bid vir 'n verdere uitstorting van die Heilige Gees. Montanus het selfs twee vroulike profetesse gehad wat, volgens hom, deur die Heilige Gees in besit geneem is en wat ook nuwe openbaringe oor die naderende wêreldeinde ontvang het en die eise wat dit aan die gelowiges stel.

Montanus en sy profetesse het die Bybel egter verkeerd verstaan en aan die Heilige Gees 'n werkwyse en 'n taak toegeskrywe wat nie volgens die Skrifte is nie. As ons Heer Jesus Christus oor die werk van die Heilige Gees praat, sê Hy:

"Wanneer Hy kom, die Gees van die waarheid, sal Hy julle in die hele waarheid lei. Want wat $\mathrm{Hy}$ sal sê, sal nie van Homself kom nie: Hy sal net sê wat Hy hoor, en Hy sal die dinge wat gaan kom, aan julle verkondig. Hy sal My verheerlik, want wat Hy van My ontvang, sal Hy aan julle verkondig" (Joh 16:13-14).

Met ander woorde die Heilige Gees sal nié 'n nuwe boodskap bring nie maar Hy sal die boodskap van die verlossing deur Jesus Christus, die gekruisigde en opgestane Heer, aan ons bring. As ons dan die gebeurtenis van Pinkster daarby betrek, dan word dit duidelik dat die Heilige Gees aan elke volk en taal en nasie in sy eie taal die evangelie van Jesus Christus sal bring. Dit is 'n groot dwaling om te dink dat die Heilige Gees in 'n onverstaanbare brabbeltaal die evangelie van Jesus Christus sal verkondig of laat verkondig.

Daarom het mense soos Thomas Müntzer, wat in 1524 onthoof is, òò gedwaal toe hy hom, teenoor die duidelike uitsprake van die Heilige Skrif, op drome, gesigte en nagtelike stemme beroep het vir sy dade en optrede. Ten onregte, kan ons sê, het hy beweer dat dit verdere openbarings van die Heilige Gees is en dat dit sy taak was om die gemeente op grond van dié "openbarings" op ander weë moes lei.

God die Heilige Gees skenk aan ons die evangelie van Jesus Christus, Hy bring die verlossing wat Jesus Christus bewerk het tot by ons deur die verkondiging van die evangelie én deur ons te omvorm en te verander sodat ons die evangelie kan hoor en glo. Die Heilige Gees lei ons deur ons oë te open vir die wonders van Gods Woord sodat ons, gelei deur daardie Woord, ons dankbaarheid teenoor God kan uitleef. Hier het Thomas Müntzer en al sy vele navolgers gedwaal om die ingewings van die eie, menslike gees, om die eie menslike gedagtes en verlangens gelyk te skakel met die werk van die Heilige Gees. Hulle dink dat die Heilige Gees maar net 'n mag of krag van God is wat aan die mens gegee word om die mens in staat te stel om allerlei dinge te doen en hulle vergeet dat die Heilige Gees God is, 'n goddelike persoon wat saam met Jesus Christus en die Vader die een, enige God is. 
Hierdie dwaling waardeur die Heilige Gees losgemaak of losgedink word van ons Heer Jesus Christus en die Woord of evangelie het ons dae ' $n$ besondere gestalte gekry. So word in die kringe van die Wêreldraad van Kerke gesê dat God in die mens se geskiedenis werksaam is. Daar is, so word gestel, nie 'n ander plek waar God en sy krag merkbaar of waarneembaar is as net onder en tussen ons mense nie.

Hierdie standpunt is in 'n betreklike sin nog waar. Maar dan word verder gegaan en gestel dat oral waar God in die lewe en geskiedenis van die mens ingryp, daar verandering en vernuwing is. Dán word sommer daar bygesê dat dit dus beteken dat oral waar daar verandering of vernuwing is, is God in die geskiedenis besig. Met ander woorde as ons God se wil en weg wil probeer raaksien en navolg, moet ons vandag net kyk waar daar vernuwing en verandering is en dan kan ons seker wees dat God daar besig is.

Hierdie argument word nou verder gevoer en dan word gesê: God is ' $n$ God van geregtigheid, God is dié God wat mense vry maak, God is die God wat Hom by uitstek met die mens vereenselwig, met die onderdruktes, die rampsaliges en uitsigloses van hierdie wêreld.

Dit beteken in die praktyk, sê die Wêreldraad van Kerke, dat God in Suidelike Afrika aan die kant van die terroriste-magte staan wat die sg blanke minderheidsregerings in Rhodesië en Suid-Afrika aanval. Want vir die Wêreldraad van Kerke is daar géén twyfel dat die terroriste vryheidsvegters is wat stryd voer teen die "blanke onderdrukkers" ten behoewe van die onderdrukte swartmense wat in Rhodesië en Suid-Afrika geregtigheid moet ontbeer, soos slawe behandel word en as die uitsigloses en die rampsaliges van hierdie aarde beskou moet word. Die terroriste voer die stryd vir vryheid, geregtigheid en menslike regte en daarom moet die terroriste verstaan word as die uitnemende instrumente van die Heilige Gees.

As dit waar sou wees, dan beteken dit dat die evangelie van Jesus Christus en die verlossing wat Hy bewerk het, by uitstek gedra en verkondig moet word deur Russies-vervaardigde outomatiese wapens, landmyne en terreur-aanvalle op weerlose mense. Dan sou dit dus ook beteken dat die apostel Paulus en almal na hom wat niks meer gedoen het as om die goeie boodskap te verkondig nie, verkeerd was. Dit word deur die Wêreldraad beaam want hulle stel ook dat die verkondiging van die woord sinloos is, dat gepraat ' $n$ mens nêrens bring nie. Die evangelie van Jesus Christus moet uitsluitlik deur dade verkondig word. Dit is al wat nog tel.

Dit klink vir ons miskien na ' $n$ belaglike redenasie en volkome vals omdat ons weet wat die terroriste kans sien om hier in Suidelike Afrika te presteer. Tog moet ons nie vergeet dat hierdie opvatting vir die Wêreldraad van Kerke heilige erns is. Daarom gee hulle ook met groot entoesiasme derduisende rande geld aan die terroriste-organi- 
sasies in die vaste oortuiging dat hulle so "die saak van God" dien. Juis omdat die Wêreldraad van Kerke se teoloë in hulle denke die verband tussen God, die Heilige Gees en Jesus Christus, die gekruisigde en opgestane Heer, laat vaar het, sien hulle ook nie meer in dat die Heilige Gees juis God is wat op sy manier sy Woord onder ons mense laat verkondig. Maar wat in die Bybel staan, is vir die teoloë van die Wêreldraad van Kerke nie meer werklik belangrik nie en die feit dat hulle die Bybelse begrippe geregtigheid, vrede, vryheid volkome vervals en verwring het, is ook nie belangrik nie. Immers, uiteindelik gaan dit vir die Wêreldraad van Kerke nie meer om die voortgang van die evangelie van Jesus Christus nie maar om die uitbreiding van die imperialistiese gesag van Sowjet-Rusland.

Dit word baie mooi geillusteer deur die gebeure in Mosambiek. Danksy die verraad van gen Antonio de Spinola het FRELIMO, die terroriste-organisasie in Mosambiek, die mag en gesag in Mosambiek in hande gekry, hoewel hulle 'n minderheid van die bevolking van Mosambiek verteenwoordig. Toe FRELIMO nog 'n terroristeoorlog teen die Portugese owerheid gevoer het, het die Wêreldraad groot bedrae geld aan FRELIMO geskenk. Volgens die denke van die Wêreldraad was en is FRELIMO mos die instrument van die Heilige Gees om vrede, geregtigheid, vryheid en menseregte in Mosambiek tot stand te bring.

Skaars was FRELIMO, danksy die verraad van de Spinola aan bewind, of hulle het ' $n$ terreurveldtog van stapel gestuur teen alles en almal wat hulle teengestaan het. Honderde mense is sonder verhoor doodgeskiet of in die tronk gestop, en daarby is alle kerklike eiendomme genasionaliseer, sendingstasies is gesluit en die meeste kerklike ampsdraers of uit die land verban of in die tronk gestop. Vandag probeer FRELIMO om 'n volkome ateïstiese, kommunistiese lewenspatroon in Mosambiek te vestig en af te dwing en almal wat Christene is, word onder swaar druk geplaas. Van die vrede, geregtigheid, vryheid en menseregte waaroor die WRK so hoog opgegee het, het die inwoners van Mosambiek nog absoluut niks gemerk nie. Maar, snaaks genoeg, dáároor is nog FRELIMO, nóg die Wêreldraad, nóg die res van die wêreld bekommerd nie.

Hieruit kan mens sien hoe dwaling oor die persoon en werk van die Heilige Gees selfs 'n sogenaamde Christelike liggaam soos die Wêreldraad van Kerke so kan mislei dat hy 'n liggaam word wat die oogmerke van die imperialisme van die godlose Sowjet-Rusland dien.

'n Ander vorm van geesdrywery vind mens ook daar waar die Heilige Gees slegs as ' $n$ mag of krag van God verstaan word wat los van Jesus Christus staan en onafhanklik van die Woord of die evangelie optree. Dit gebeur veral in daardie kringe wat in 'n meerdere of ' $n$ 
mindere mate onder die bekoring van die metodisme gekom het. Hier word gewoonlik die voorstelling gehuldig dat die koms van God, die Heilige Gees na ons wêreld nié by Pinkster in Jerusalem voltooi is nie. Omdat die Heilige Gees as 'n mag of krag van God verstaan word en nie as 'n goddelike persoon nie, word geoordeel dat die Heilige Gees herhaaldelik uitgestort kan word en moet word. Terselfdertyd word dan geoordeel dat die "iets soos vuur" wat in "tonge" verdeel het en op elkeen van die dissipels neergedaal het, die "geluid soos van 'n geweldige stormwind" en die "ander tale" waarin die dissipels begin praat het, volgens die mededeling in die Boek van die Handelinge die waarborge is van ' $n$ "uitstorting" van die Heilige Gees. Daarom word in dié kringe alles in die werk gestel om by samekomste iets dergliks te laat gebeur sodat hulle op 'n verdere "uitstorting van die Heilige Gees" aanspraak kan maak.

Hier word, minstens, die bykomstige dinge met die saak self verwar. As ons hierdie redenasie op die koms van ons Heer Jesus Christus sou toepas, sou ons moet sê dat by Kersfees die krip en die strooi en die stal die belangrike is en dat dit die uiterlike waarborge is dat die Seun van God na ons wêreld gekom het.

Juis omdat die metodiste en baie sektariese groeperinge, wat op die lees van die metodisme geskoei is, hierdie fout maak, gee hulle'n heeltemal skewe voorstelling van God, die Heilige Gees, wat 'n persoon in die goddelike Drie-eenheid is. Al die sogenaamde "bekeringsdienste" wat in hierdie groepe se midde gehou word waar ekstase, die praat van 'n onverstaanbare brabbeltaal en derglike meer as waarborge vir die teenwoordigheid van die Heilige Gees gesien word, gaan mank aan hierdie een saak en dit is dat die Heilige Gees nié as God self gesien word nie maar slegs as 'n mag of krag van God wat afgebid kan word en wat dan in allerlei menslike doenighede na vore kom.

Dan word vergeet dat op Pinksterdag in Jerusalem, nadat God die Heilige Gees in die midde van die dissipels neergedaal het, Petrus die visserman opstaan en in duidelike en verstaanbare taal 'n oortuigende verkondiger van die evangelie van Jesus Christus word. Terselfdertyd bekeer God, die Heilige Gees, op dié dag 3000 mense. Dit is nié 3000 mense wat hulle tot God bekeer nie maar God die Heilige Gees wat sy teenwoordigheid as God-in-ons-midde as 't ware demonstreer deur 3000 mense tot die getal van die gemeente toe te voeg. Juis omdat in die metodisme die Heilige Gees verwar word met 'n krag of mag van God dáárom word gedink dat die mens se gees dieselfde is as die Heilige Gees.

'n Soortgelyke misvatting heers soms ook binne die sg charismatiese beweging waar baie klem gelê word op gebedsgenesings en wonderdoenery wat dan onmiddellik aangeprys word as waarborge 
vir die teenwoordigheid en werksaamheid van die Heilige Gees. Dit wil my voorkom dat as ons hierdie sake wil beoordeel, ons altyd die kern-uitspraak van ons Heer Jesus Christus in gedagte moet hou waar Hy gesê het: "Wat Hy van My ontvang, sal Hy aan julle verkondig." Ek dink tog dat ons die werk van die Heilige Gees beter kan "sien" oral daar waar God, die Heilige Gees, gewone mense gebruik om die Woord van God, die evangelie reg te verkondig sodat daar gelowiges rondom die Woord bymekaarkom en bly. Maar vir baie mense is dit te "gewoon" en daarom moet allerlei dramatiese en andersoortige dinge gedoen word asof God, die Heilige Gees alleen daar en so gesien kan word.

\section{Dwaling rondom die leer van die kerk}

'n Baie hardnekkige dwaling romdom die werk van die Heilige Gees is ook dié een wat ons aantref in die Roomse leer oor die kerk. Daar word geleer dat die Heilige Gees alleen in en deur die kerk in ons wêreld werksaam is. Anders as by ons Hervormde vadere wat op die voetspoor van die Skrif geleer het dat God, die Heilige Gees ten nouste met ons Heer Jesus Christus verbonde is en dat Hy deur die verkondigde Woord in ons midde is en werksaam bly, sien die Roomse teologie dit so dat God, die Heilige Gees ten nouste met die kerk gekoppel is.

Daarom is by Rome die kerk ook ' $n$ heilsinstituut, 'n instelling, 'n liggaam waardeur die mens die heil, die saligheid wat Jesus Christus vir ons verwerf het, sal ontvang. Nie deur die geloof nie, nie deur die verkondigde Woord nie, nie deur die onfeilbare boodskap van die Heilige Skrif nie, maar deur die kerk word die mens salig, so leer Rome. Daarom leer Rome ook dat die kerk onfeilbaar is. Omdat die kerk egter uit mense bestaan, is dit ' $n$ stelling wat nie so maklik is om te handhaaf nie. Daarom leer Rome dat die kerk eintlik die amp is. Die amp is die kerk en dan verder is daar in die Roomse kerk eintlik net één amp en net één ampsdraer en dit is die pous wat aangedui word as die opvolger van Petrus. Hy is die onfeilbare ampsdraer. Hy besit die Heilige Gees en hy is die onfeilbare verteenwoordiger van Jesus Christus op aarde. So gebeur dit in die Roomse teologie dat Jesus Christus die gekruisigde en opgestane Heer, nie werklik belangrik geag word nie. Die uitnemende belangrike persoon is die pous, die sigbare, aardse verteenwoordiger van Jesus Christus op aarde, die verpersoonliking van die Heilige Gees onder die mense.

In die Roomse kerk is die aartsbiskoppe, die biskoppe, die priesters en die ander ampsdraers baie belangrik want hulle ontvang hulle bevoegdheid en gesag van die pous. Deur hulle hande kanaliseer hulle die genade en die ewige heil onfeilbaar na die lidmaat van die Roomse kerk. Die ampsdraers is mos die verteenwoordigers van die 
onfeilbare verteenwoordiger van Christus op aarde. Hulle is die verteenwoordigers van die verpersoonlikte Heilige Gees op aarde wat in die stad Rome, in die luukse en weelde van die Vatikaanpaleis woon.

Dit is dan ook opvallend dat in die Roomse kerk die verkondiging van die Woord, die evangelie van Jesus Christus géén sentrale plek inneem nie. Nie die geloof in die evangelie nie maar die vertroue op die kerk, die vertroue op die pous en die heil wat hy skenk, sal die Roomse lidmaat salig maak want die pous bemiddel die heil, hy is, as die verteenwoordiger van die Heilige Gees, die enigste kanaal waardeur die heil van God na die mens kan vloei.

\section{Slotopmerkings}

Dit is natuurlik moontlik om nog meer dwalings in meer besonderhede hier na vore te haal. Tog is dit nie so belangrik nie al is dit so dat mens dikwels baie kan leer uit dit wat as verkeerd geag moet word.

Dit wil my egter voorkom dat as ons onsself teen allerlei dwalings oor die persoon en werk van die Heilige Gees wil vrywaar, ons die derde deel van ons geloofsbelydenis nl die Twaalf Artikels, altyd sorgvuldig in gedagte moet hou. Dáár bely ons dat die Heilige Gees God is en in die opvolgende artikels bely ons wat ons glo wat dit beteken dat God, die Heilige Gees, op Pinksterdag in Jerusalem eens en vir altyd na ons sondaar-mense toe gekom het.

Dit alles word ook baie mooi saamgevat in Antwoord 53 van die Heidelbergse Kategismus waar ons saam met die kerk bely:

"Wat glo u van die Heilige Gees?

Eerstelik, dat Hy saam met die Vader en die Seun waaragtige en ewige God is;

Ten tweede dat Hy ook aan my gegee is om my deur ' $n$ opregte geloof Christus en al sy weldade deelagtig te maak, my te troos en ewig by my te bly." 